\title{
Embryo stem-cell work gets NIH go-ahead
}

\section{Paul Smaglik, Washington}

US researchers can at last apply for federal grants to study human embryonic stem cells. The go-ahead came last week when the National Institutes of Health $(\mathrm{NIH})$ published the long-awaited terms under which it will fund such research. In principle, grants submitted now could be reviewed as soon as December and funded in the fiscal year 2001, which starts next October.

The move comes hard on the heels of a similar decision by the British government two weeks ago (see Nature 406, 815;2000). It ends a de facto moratorium on US government support for embryonic stem-cell research, in place since the cells were first cultured successfully two years ago.

But the research allowed by the guidelines could be short-lived. The rules are based on an interpretation of the present laws banning the use of public funds for human embryo research, which could be reversed after this year's presidential elections.

In January 1999, the Department of Health and Human Services said that these laws - which are based on the fact that embryos are destroyed when the stem cells are extracted from them - do not apply to their stem cells, as these are not themselves embryos (see Nature 397, 185; 1999).

In a twist that even some stem-cell supporters find tenuous, the guidelines

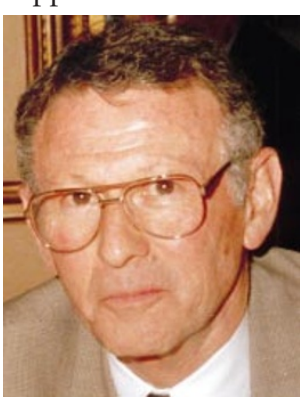

Berg: it is too early to focus only on adult cells.

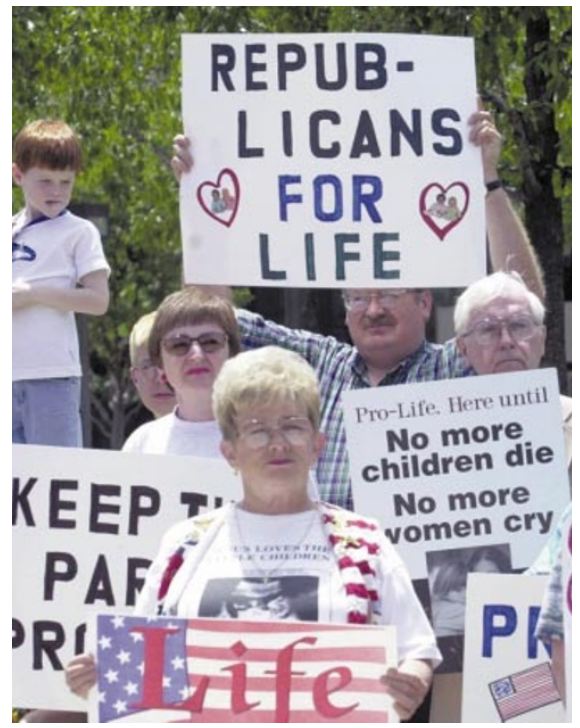

Hot potato: opposition from anti-abortionists could still shift political views in Washington.

they would either sue the NIH to stop the research or draft legislation to prohibit it, others are trying to expand it. Senator Arlen Specter (Republican, Pennsylvania), for example, has drafted a bill that would allow federal funding for both use and derivation of embryonic stem cells.

Although the guidelines were issued in draft form last winter, the NIH has tried to defuse the controversy by creating a greater distinction between the derivation and the use of embryonic stem cells, and by applying tighter controls. For example, the new guidelines require, rather than recommend, an institutional review board's approval for the derivation of stem cells from both embryos and fetal tissue.

The most significant modification, says
Lana Skirboll, associate director for science policy at the NIH, is that the guidelines now allow donors of embryonic stem cells to be identified - the original guidelines required that their identity be masked.

Knowing the identity of donors could help minimize immune responses when cells are transplanted into other humans and also prevent infectious diseases from being transmitted.

Researchers will also have to specify what types of experiments they intend to perform. If they use stem cells for work not included by the guidelines, they could jeopardize other NIH funding for their institutions.

Scientific societies, including the American Society for Cell Biology and the Federation of American Societies for Experimental Biology have welcomed the guidelines, as have several patient advocacy groups. President Bill Clinton endorsed them, but Pope John Paul II denounced them.

Opponents say that the NIH should support more work on adult stem cells (see Nature 405, 6; 2000). David Prentice, professor of life sciences at Indiana State University and a member of Do No Harm, a group that opposes embryonic stem-cell research, says that adult stem cells have been unfairly maligned.

He says that recent research raises questions about the claims that adult stem cells cannot differentiate into as many cell types, or produce as many cells as embryonic ones. "They actually have a lot more promise and they don't have the ethical baggage," he says.

But Nobel laureate Paul Berg, professor of biochemistry at Stanford University, says concentrating only on adult stem cells would be premature. "This line of research is still in its infancy," he says. will use only plus embryos that would be discarded after in vitro fertilization treatment. Both antiabortionists and members of the National Bioethics Advisory Commission, which supports stem-cell research, have criticized the logic behind this.

The lack of a strong legal basis, together with opposition from the anti-abortion lobby, is making embryonic stem-cell research - already a volatile issue in the United States - a prominent political lightning rod. US presidential candidate George W. Bush has said through spokesmen that he opposes such research. If elected in November, some fear that he could sign an executive order forbidding it. In contrast, Democrat candidate Al Gore has said he supports stemcell research.

The US Congress is also sharply split. Although some members have indicated that

\section{Japan seeks science entrepreneurs}

David Cyranoski, Tokyo

Japan's Ministry of International Trade and Industry (MITI) has linked up with the country's ministries of education and health to tackle a tricky problem: how to spur joint public-private research.

The result is the creation of two threeyear grant programmes to fund joint research projects in new industries, with the hope of paving the way for commercialization and start-up companies.

Grants funded by MITI and the Ministry of Education, Science, Sports and Culture (Monbusho) will be targeted at information technology, energy/environment and biotechnology. Grants for work by industry and the Ministry of Health will target the development of instruments for the diagnosis and treatment of heart disease and cancer, as laid out in the Medical Frontiers programme announced this spring.

The scale is small. But "the cooperation between ministries, and its establishment as a permanent part of the budget are quite significant accomplishments in a Japanese setting," says Yukio Kawaguchi, who runs MITI's collaboration with Monbusho.

MITI expects to receive most of the $¥ 1$ billion (US\$9.3 million) it will request from the government for the grants with Monbusho, and probably a large fraction of its request for those with the health ministry. Selected projects will receive about $¥ 100$ million from MITI; industry would 
need to invest half that again.

A programme announced last year for joint research between industry and universities was financed from a supplementary budget, meaning that the money had to be spent in one year - a short period to develop new technologies, say MITI officials (see Nature 402, 116; 1999).

Koichi Sumikura of Tokyo

University's Research Center for Advanced Science and Technology agrees that a three-year budget will "allow rollover and avoid some wastefulness of projects whose budget must be exhausted in one year". At the end of three years, government support would end and, it is envisioned, entrepreneurs would be able to exploit the joint research.

University researchers' enthusiasm for the project is still in doubt. The lifting of some restrictions, which allowed researchers to take up executive positions in companies (see Nature 403, 589; 2000), has yet to stir much interest.

Part of the problem, says Kawaguchi, is that "universities are less demanding than in the United States, and many researchers will tell you they are simply too comfortable to take a risk in industry". The current programme is designed to allow them to develop their technologies, and perhaps gain some new research equipment, without risk.

But problems with intellectual property could lessen industry's interest in joint research. Any action taken on a patent in Japan must be agreed to by all holders. Thus, even if a university were to hold only a small share of the patent, warns one Ministry of Health official, the prospective entrepreneur "would have to deal with lengthy bureaucratic deliberations on the use of the patent".

MITI's Medical and Welfare

Equipment Industries section chief Yukiko Araki admits that, although MITI and the health ministry share the same goals, many details of funding and other procedural matters are still in need of attention.

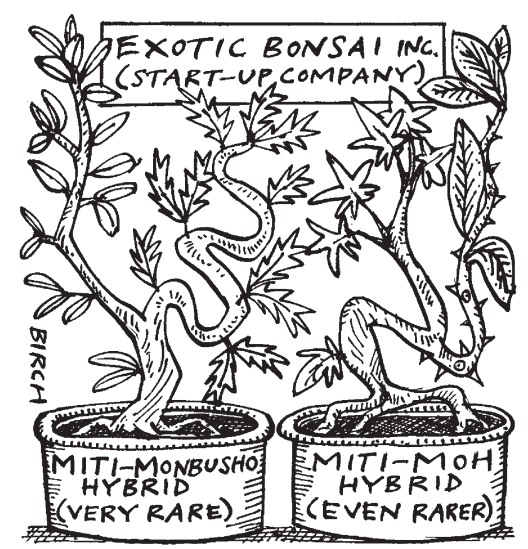

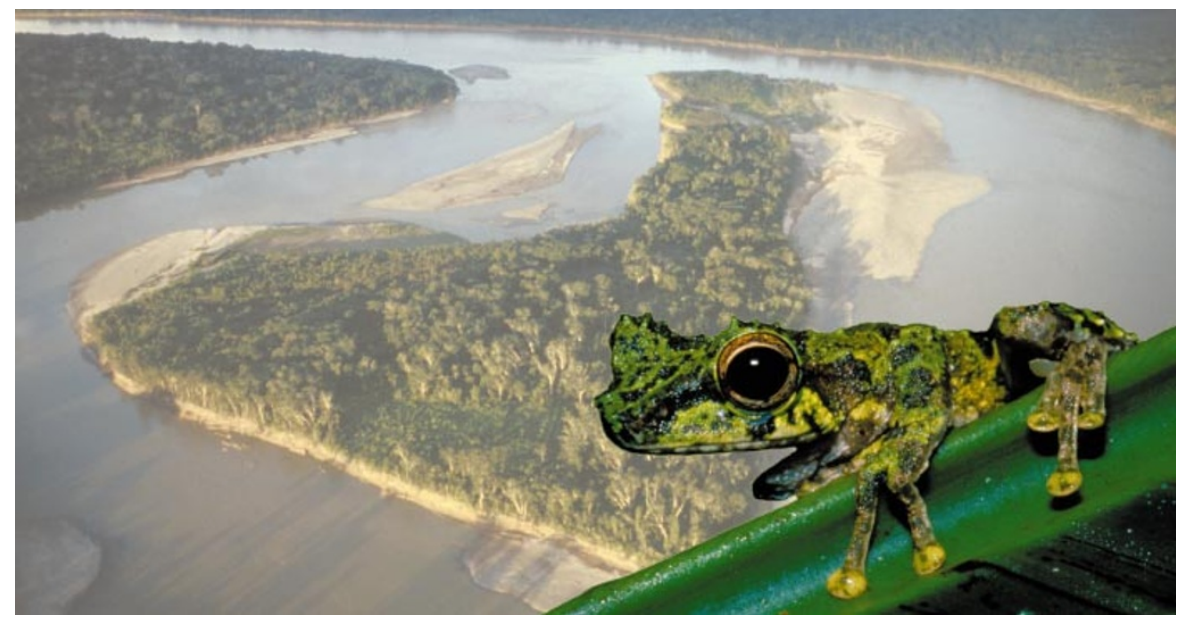

Safe? Species such as this newly discovered Indonesian frog could benefit from the biodiversity plan.

\section{Ecologists back blueprint to save biodiversity hotspots}

\section{Rex Dalton, Pasadena}

Eminent ecologists have endorsed a multibillion dollar blueprint for the conservation of biodiversity hotspots around the world, deflecting concerns about the scope and cost of the plan.

Conservation International (CI), a Washington-based non-profit organization invited leading lights of the biodiversity research community, such as Harvard University's Edward Wilson, to discuss the proposal at a four-day meeting at the California Institute of Technology last week.

"If we are going to have an impact on saving biodiversity, we have to approach this on a scale far beyond anything proposed before," says CI president Russell Mittermeier.

CI officials hope that philanthropists and private individuals will make the huge donations needed to support the conservation efforts. The first step towards this goal was taken recently, with the announcement of a \$75 million Critical Ecosystem Partnership Fund, which is expected to double in size within months (see Nature406, 818;2000).

The 25 biodiversity hotspots targeted for preservation under the blueprint cover $1.4 \%$ of the Earth's land area, but contain an estimated $44 \%$ of vascular plant species and $35 \%$ of all species in four major vertebrate groups. The hotspots — including areas of Latin America, Africa, Madagascar, India and Southeast Asia - were described earlier this year in an article by CI scientists and their co-workers (see Nature 403, 853-858; 2000).

Participants at last week's symposium said that conservation efforts should reach beyond these locations to save three wilderness regions threatened by forestry, mining and ranching. These are the Amazon Basin and the Guyana shield region in South
America, and the Congo Basin in Africa.

A draft document - called An Agenda to Defy Nature's End - was drawn up by the scientists to focus research programmes, develop local preservation efforts and reduce incentives for the destruction of biodiversity.

But the costs of preservation, management and running a research centre at each biodiversity hotspot could be nearly $\$ 200$ million a year in each case, CI officials say. Protecting the three wilderness areas could cost an additional $\$ 4$ billion, says Mittermeier, adding that he hopes to raise $\$ 1$ billion in private money to jump-start this effort.

CI's plan has sparked debate among ecologists, with some questioning whether there are enough data to identify the hotspots most worth saving. The meeting heard from some of the sceptics, including Andrew Dobson, an evolutionary biologist at Princeton University, and Andrew Balmford, a zoologist at Cambridge University, who have publicly challenged the proposal (see Nature 405, 393; 2000).

Stuart Pimm, a conservation biologist at Columbia University in New York who led the discussion of the blueprint, says that "a broad consensus on what needs to be done" emerged from the meeting.

But Jeff McNeely, chief scientist for the Swiss-based World Conservation Union says that CI needs to reach out to governments whose nations include the hotspots, so as to introduce more reality into its planning.

"Governments often don't like biodiversity," McNeely points out. "They are trying to build nations. I am very supportive of what CI is trying to accomplish. But if you are going to design something that works, you have to talk to the opposition."

http://www.conservation.org

http://www.defyingnaturesend.org 